\title{
Financial Strength and Weakness of Selected Pharmaceutical Companies in India
}

\author{
A. Jalaudeen, M. Marimuthu
}

\begin{abstract}
The Indian pharmaceutical industries are one of the very good developing industries. The Indian Pharmaceutical companies producing drug through the world. India is the top three medicine producing and export country in the world and $50 \%$ various medicines supplied to the world by Indian Pharmaceutical Companies. The objectives of the study is explore strength and weakness of selected pharmaceutical companies in India and identify the profitability position of selected Indian Pharmaceutical companies.

The reason for chosen this topic is The pharmaceutical industry is one of the ever green industries in India. But in recent days performance of the pharmaceutical companies is came down. In National Stock Exchange the performance of Indian pharma company was very low in the financial year 2018-19. The interpretation of the study is The above tables and Charts shows that, the Net profit of Sun Pharma is 2017 -7,836.30,20182,633.79 and 2019-3,209.32.Begining of the year it was very high, then decrease after increased. Drreddys Net profits 20171,257.20, 2018 -912.401 and 2019-1,906.20.
\end{abstract}

Keywords: Pharma, Selected Indian pharma, SUN pharma

\section{PRELUDE}

The Indian pharmaceutical industries are one of the very good developing industries. The Indian Pharmaceutical companies producing drug through the world. India is the top three medicine producing and export country in the world and 50\% various medicines supplied to the world by Indian Pharmaceutical Companies. More over they supplied $40 \%$ primary demand to US people and 25\% supplied to people living in United Kingdom. The Government of India, recently started to encourage the development of drugs producer by Indian companies in the early 1960, and with the Act of Patent in 1970. However, the Former Prime Minister Mr. P. V. Narasimha Rao and Dr. Manmohan Singh- Former Finance Minister of India introduced New Economic Policy to develop the Indian industry to beat world competitors. Indian companies impressed a role in both the Indian and global markets with their proficiency in reverse-engineering new processes for mechanized drugs at low costs which become the improvement for pharmaceutical Industries.

The bio-pharmaceutical industry in india clocked a 17 percent development with income of Rs. 137 billion in the 2009-10 financial year over the previous fiscal year. The largest supplier in India, Bio-Pharma creating 60 percentage of the Pharma industry's development at Rs.8,829, and follow by Bio-services at Rs.2639 Crores and Bio-Agri at Rs. 1936 crores.

Revised Manuscript Received on December 05, 2019.

Mr. A. Jalaludeen, Assistant professor, SRM Institute of Science and Technology, Chennai, India.

Dr. M. Marimuthu, Assistant Professor, PG \& Research Department of Commerce in Jamal Mohamed College, Trichy. India.

\section{A. Objectives of the Study}

- To explore strength and weakness of selected pharmaceutical companies in India.

- To identify the profitability position of selected Indian Pharmaceutical companies.

- To know about liquidity position selected Indian Pharmaceutical companies.

\section{REVIEW OF LITERATURE}

Agarwal, S., Desai, S., Holcomb, M. and Oberoi, A., (2001), offered the study on pharmaceutical industry. In India, the pharmaceutical industry straightly employed around 500,000 citizens and is highly scrappy. While there are around 270 huge Research \& Development based pharmaceutical companies in India, including multinational corporations, government owned and private owned companies, there are also approximately 5,600 slighter qualified generics producers, even though in certainty only approximately 3,000 companies are complicated in pharmaceutical production.

Baum. A, Baisiwal. S, Goodman. M., and Rubin, J (2003), have presented inquiry into the drug business in India. They said that 35 per cent of business is in the ground of new drug detection and remaining 65 per cent of business is in the medical trials field. India offers a vast cost improvement in the experimental trials field compared to Western countries.

\section{RESEARCH METHODOLOGY}

The researcher used secondary data collection in this paper. The data collected from various resources such as, Books, Journals, IBEF, Fundoodata and some other sources from internet.

\section{A. Population size}

Totally in India 2037 pharmaceutical companies are there. From this, the researcher have taken top 3 private sector pharmaceutical companies based on total capitalization listed by Nifty Pharma indices for analysis. The companies are Sunpharma, Cipla and Divislab.

\section{B. Statement of the Problem}

The pharmaceutical industry is one of the ever green industries in India. But in recent days performance of the some Indian pharmaceutical companies is came down. In National Stock Exchange the performance of Indian pharma company was very low in the financial year 2018-19. 
This study will help to know the strength and Weakness of selected Indian Pharmaceutical companies in India. So that the researcher chosen this topic to know the reason for the decline.

\section{Sampling Method}

The researcher used simple random sampling method for analysis. Since the researcher has indentified the population size. So that he chosen Probability sampling method.

\section{Tools for analysis}

The researcher used Accounting Ratio, Trend Analysis for analysis the Strength and Weakness of Indian Pharmaceutical companies.

- Ratio analysis

- Trend analysis

- Altman Z-Score Analysis

\section{ANALYSIS AND INTERPRETATION}

Table No.1

\begin{tabular}{|l|l|l|l|l|l|l|}
\hline & \multicolumn{5}{|l}{ Net Profits } & \multicolumn{2}{l|}{ Sales } \\
\hline & $\begin{array}{l}\text { Sunpharm } \\
\text { a }\end{array}$ & $\begin{array}{l}\text { Drredd } \\
\text { ys }\end{array}$ & Cipla & $\begin{array}{l}\text { Sunphar } \\
\text { ma }\end{array}$ & $\begin{array}{l}\text { Drredd } \\
\text { ys }\end{array}$ & Cipla \\
\hline 2017 & 7836.30 & 1257.2 & $1,042.4$ & $29,993.9$ & $14,080$. & 14,04 \\
& & 0 & 1 & 3 & 90 & 4.91 \\
\hline 2018 & $2,633.79$ & 912.40 & $1,419.3$ & $25,992.0$ & $14,202$. & 14,68 \\
& & & 5 & 2 & 80 & 7.32 \\
\hline 2019 & $3,209.32$ & $1,906.2$ & $1,509.6$ & $28,686.2$ & $14,870$. & 15,97 \\
& & 0 & 1 & 8 & 60 & 0.97 \\
\hline
\end{tabular}

Table No.2

\begin{tabular}{|l|l|l|l|l|l|l|}
\hline \multicolumn{4}{|l|}{ Current Assets } & \multicolumn{3}{l|}{ Current Liability } \\
\hline & $\begin{array}{l}\text { Sunphar } \\
\text { ma }\end{array}$ & $\begin{array}{l}\text { Drreddy } \\
\text { s }\end{array}$ & Cipla & $\begin{array}{l}\text { Sunphar } \\
\text { ma }\end{array}$ & $\begin{array}{l}\text { Drredd } \\
\text { ys }\end{array}$ & Cipla \\
\hline 201 & $32,953.6$ & $9,683.7$ & $8,804.6$ & $17,887$. & $8,419$. & 3,373 \\
7 & 5 & 0 & 3 & 02 & 90 & .70 \\
\hline 201 & $31,635.9$ & $10,498$. & $10,814$. & $19,864$. & $6,893$. & 3,832 \\
8 & 0 & 40 & 10 & 32 & 80 & .22 \\
\hline 201 & $31,069.1$ & $11,450$. & $12,426$. & $17,339$. & $5,897$. & 3,771 \\
9 & 9 & 10 & 63 & 62 & 30 & .51 \\
\hline
\end{tabular}

Table No.3

\begin{tabular}{|c|c|c|c|c|c|c|}
\hline & \multicolumn{3}{|c|}{ Working Capital } & \multicolumn{3}{|c|}{ Total Assets } \\
\hline & $\begin{array}{l}\text { Sunphar } \\
\text { ma }\end{array}$ & $\begin{array}{l}\text { Drredd } \\
\text { ys }\end{array}$ & Cipla & $\begin{array}{l}\text { Sunpha } \\
\text { rma }\end{array}$ & $\begin{array}{l}\text { Drredd } \\
\text { ys }\end{array}$ & Cipla \\
\hline 2017 & $\begin{array}{c}15066.6 \\
3\end{array}$ & 1263.8 & $\begin{array}{c}5430.9 \\
3\end{array}$ & $\begin{array}{c}61,410 . \\
24\end{array}$ & $\begin{array}{c}21,816 . \\
50\end{array}$ & $\begin{array}{c}21,037 . \\
07\end{array}$ \\
\hline 2018 & $\begin{array}{c}11771.5 \\
8\end{array}$ & 3604.6 & $\begin{array}{c}6981.8 \\
8\end{array}$ & $\begin{array}{c}64,302 . \\
80\end{array}$ & $\begin{array}{c}22,544 . \\
30\end{array}$ & $\begin{array}{c}22,860 \\
55\end{array}$ \\
\hline \multirow[t]{3}{*}{2019} & $\begin{array}{c}13729.5 \\
7\end{array}$ & 5552.8 & $\begin{array}{c}8655.1 \\
2\end{array}$ & $\begin{array}{c}64,693 \\
81\end{array}$ & $\begin{array}{c}22,465 \\
60\end{array}$ & $\begin{array}{c}23,963 . \\
32\end{array}$ \\
\hline & \multicolumn{3}{|c|}{ Retained Earnings } & \multicolumn{3}{|c|}{ Market Capitalization } \\
\hline & $\begin{array}{c}\text { Sunphar } \\
\text { ma }\end{array}$ & $\begin{array}{c}\text { Drredd } \\
\text { ys }\end{array}$ & Cipla & $\begin{array}{c}\text { Sunpha } \\
\text { rma }\end{array}$ & $\begin{array}{c}\text { Drredd } \\
\text { ys }\end{array}$ & Cipla \\
\hline 2017 & $\begin{array}{c}36,399.7 \\
4\end{array}$ & $\begin{array}{c}12,179 \\
20\end{array}$ & $\begin{array}{c}12,382 \\
76\end{array}$ & $\begin{array}{c}36,639 \\
67\end{array}$ & $\begin{array}{c}12,262 \\
10\end{array}$ & $\begin{array}{c}12,543 \\
66\end{array}$ \\
\hline 2018 & $\begin{array}{c}37,860.6 \\
3\end{array}$ & $\begin{array}{c}12,488 \\
60\end{array}$ & $\begin{array}{c}14,068 . \\
17\end{array}$ & $\begin{array}{c}38,100 . \\
56\end{array}$ & $\begin{array}{c}12,571 \\
60\end{array}$ & $\begin{array}{c}14,229 \\
19\end{array}$ \\
\hline 2019 & $\begin{array}{c}41,169.1 \\
3\end{array}$ & $\begin{array}{c}13,940 \\
60\end{array}$ & $\begin{array}{c}14,851 \\
14\end{array}$ & $\begin{array}{c}41,409 . \\
06\end{array}$ & $\begin{array}{c}14,023 \\
60\end{array}$ & $\begin{array}{c}15,012 \\
28\end{array}$ \\
\hline
\end{tabular}

Published By:

Blue Eyes Intelligence Engineering

Table No.4

\begin{tabular}{|l|l|l|l|l|l|l|}
\hline & \multicolumn{5}{|c|}{ Total Liabilities } & \multicolumn{2}{l|}{ Profit Before Interest And Tax } \\
\hline & $\begin{array}{l}\text { Sunphar } \\
\text { ma }\end{array}$ & $\begin{array}{l}\text { Drredd } \\
\text { ys }\end{array}$ & Cipla & $\begin{array}{l}\text { Sunpharm } \\
\text { a }\end{array}$ & Drreddys & Cipla \\
\hline 20 & $61,410$. & 21,816 & 21,037 & $9,047.87$ & $1,553.70$ & $1,222.1$ \\
17 & 24 & .50 & .07 & & & 7 \\
\hline 20 & $64,302$. & 22,544 & 22,860 & $4,429.48$ & $1,350.40$ & $1,746.9$ \\
18 & 80 & .30 & .55 & & & 8 \\
\hline 20 & $64,693$. & 22,465 & 23,963 & $5,024.58$ & $2,292.00$ & $2,079.1$ \\
19 & 81 & .60 & .32 & & & 4 \\
\hline
\end{tabular}

Table No.5

\begin{tabular}{|l|r|r|r|}
\hline & \multicolumn{2}{|l|}{ Revenue } & \multicolumn{2}{l|}{ Cipla } \\
\hline & \multicolumn{1}{|l|}{ Sunpharma } & \multicolumn{1}{l|}{ Drreddys } & $14,622.98$ \\
\hline 2017 & $31,931.29$ & $14,367.60$ & $15,513.36$ \\
\hline 2018 & $27,254.30$ & $14,436.20$ & $16,838.98$ \\
\hline 2019 & $30,091.40$ & $15,785.70$ & \\
\hline
\end{tabular}

Table No.6

\begin{tabular}{|c|c|c|c|c|c|c|}
\hline & \multicolumn{3}{|c|}{ Net Profits Ratio } & \multicolumn{3}{|c|}{$\begin{array}{l}\text { Working Capital / Total } \\
\text { Assets Ratio (X1) }\end{array}$} \\
\hline & $\begin{array}{l}\text { Sunphar } \\
\text { ma }\end{array}$ & Drreddys & Cipla & $\begin{array}{l}\text { Sunph } \\
\text { arma }\end{array}$ & Drreddys & Cipla \\
\hline 2017 & 26.13 & 8.93 & 7.42 & 0.25 & 0.06 & 0.26 \\
\hline 2018 & 10.13 & 6.42 & 9.66 & 0.18 & 0.16 & 0.31 \\
\hline 2019 & 11.19 & 12.82 & 9.45 & 0.21 & 0.25 & 0.36 \\
\hline
\end{tabular}

Table No.7

\begin{tabular}{|c|c|c|c|c|c|c|}
\hline & \multicolumn{3}{|c|}{$\begin{array}{l}\text { Retained Earnings / Total } \\
\text { Assets (X2) }\end{array}$} & \multicolumn{3}{|c|}{$\begin{array}{l}\text { Profit Before Interest and Tax } \\
\text { / Total Assets (X3) }\end{array}$} \\
\hline & $\begin{array}{l}\text { Sunp } \\
\text { harm } \\
\text { a }\end{array}$ & Drreddys & Cipla & $\begin{array}{l}\text { Sunpha } \\
\text { rma }\end{array}$ & Drreddys & Cipla \\
\hline 2017 & 0.59 & 0.56 & 0.59 & 0.15 & 0.07 & 0.06 \\
\hline 2018 & 0.59 & 0.55 & 0.62 & 0.07 & 0.06 & 0.08 \\
\hline 2019 & 0.64 & 0.62 & 0.62 & 0.08 & 0.10 & 0.09 \\
\hline
\end{tabular}

Table No.8

\begin{tabular}{|c|c|c|c|c|c|c|}
\hline & \multicolumn{3}{|c|}{$\begin{array}{l}\text { Market Equity Capitalization / } \\
\text { Total Liability (X4) }\end{array}$} & \multicolumn{3}{|c|}{ Revenue / Total Assets (X5) } \\
\hline & $\begin{array}{l}\text { Sunpharm } \\
\text { a }\end{array}$ & $\begin{array}{l}\text { Drreddy } \\
\text { s }\end{array}$ & Cipla & $\begin{array}{l}\text { Sunpharm } \\
\text { a }\end{array}$ & $\begin{array}{l}\text { Drre } \\
\text { ddys }\end{array}$ & Cipla \\
\hline 2017 & 0.60 & 0.56 & 0.60 & 0.52 & 0.66 & 0.70 \\
\hline 2018 & 0.59 & 0.56 & 0.62 & 0.42 & 0.64 & 0.68 \\
\hline 2019 & 0.64 & 0.62 & 0.63 & 0.47 & 0.70 & 0.70 \\
\hline
\end{tabular}

\section{A. Altman Guidelines for Financial Healthy Zone}

$\mathrm{Z}=$ weighted average of five ratios

$\mathrm{X} 1$ = working capital / total assets

$\mathrm{X} 2$ = retained earnings / total assets

$\mathrm{X} 3=$ profit before interest and tax / total assets 
X4 = market equity capitalization / Total Liabilities

X5 = Revenue / total assets

$\mathrm{Z}=\mathrm{X} 1+\mathrm{X} 2+\mathrm{X} 3+\mathrm{X} 4+\mathrm{X} 5$

Table No.9

\begin{tabular}{|c|c|c|c|c|c|c|}
\hline & \multicolumn{3}{|c|}{ CURRENT RATIO } & \multicolumn{3}{|l|}{ ROCE } \\
\hline & $\begin{array}{l}\text { Sunph } \\
\text { arma }\end{array}$ & $\begin{array}{l}\text { Drreddy } \\
\text { s }\end{array}$ & Cipla & $\begin{array}{l}\text { Sunph } \\
\text { arma }\end{array}$ & $\begin{array}{l}\text { Drre } \\
\text { ddys }\end{array}$ & Cipla \\
\hline 2017 & 1.84 & 1.15 & 2.61 & 0.23 & 0.12 & 0.07 \\
\hline 2018 & 1.59 & 1.52 & 2.82 & 0.11 & 0.09 & 0.09 \\
\hline 2019 & 1.79 & 1.94 & 3.29 & 0.11 & 0.14 & 0.10 \\
\hline
\end{tabular}

Table No.10

\begin{tabular}{|l|c|c|c|}
\hline & \multicolumn{3}{|c|}{ Altman Z SCORE } \\
\hline & Sunpharma & Drreddys & Cipla \\
\hline 2017 & 2.11 & 1.91 & 2.21 \\
\hline 2018 & 1.85 & 1.97 & 2.31 \\
\hline 2019 & 2.04 & 2.29 & 2.4 \\
\hline
\end{tabular}

Chart No. 1

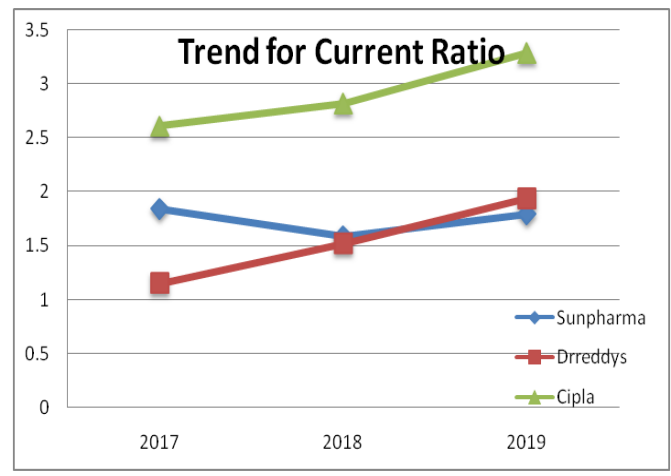

Chart No. 2

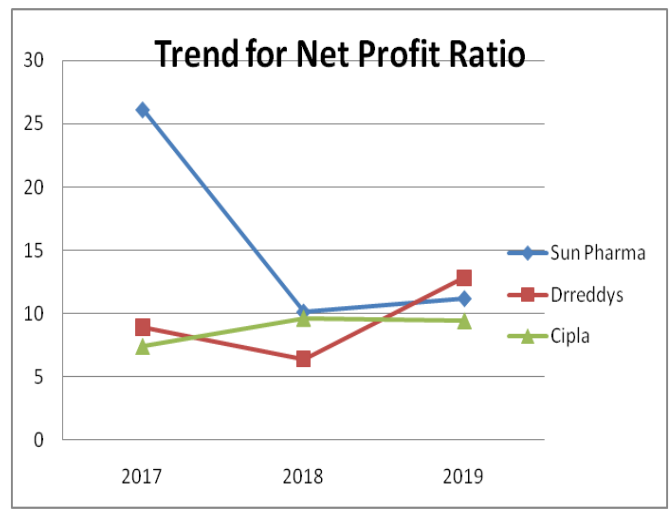

Chart No. 3

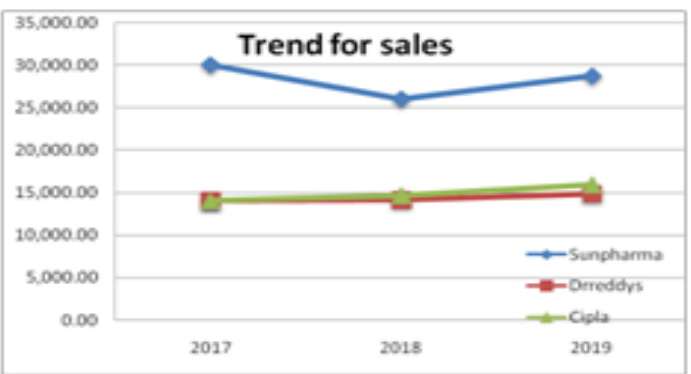

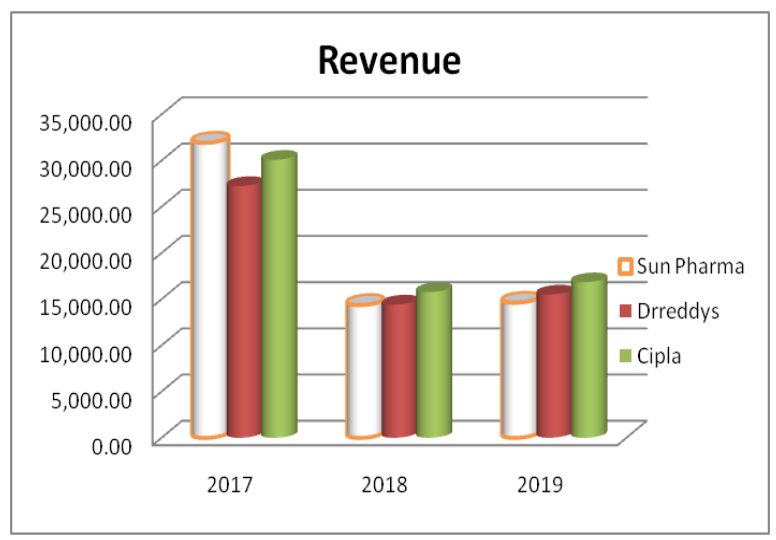

Chart No. 5
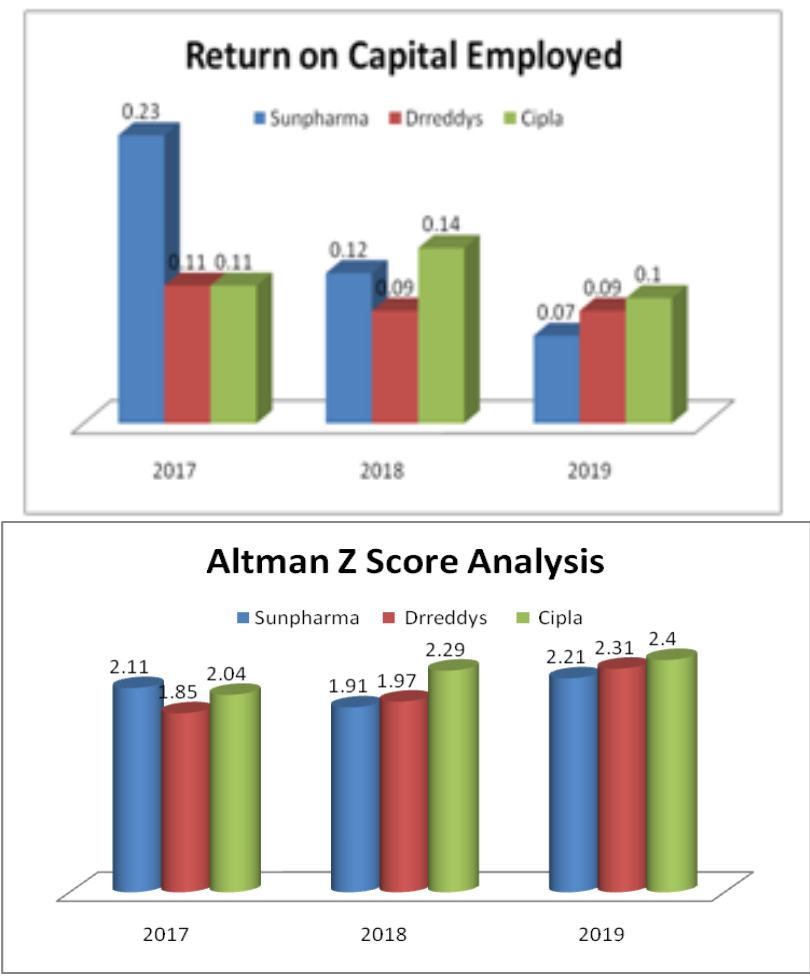

Chart No. 6

\section{B. Interpretation}

The above tables and Charts shows that, the Net profit of Sun Pharma is $2017-7,836.30,2018-2,633.79$ and 20193,209.32.Begining of the year it was very high, then decrease after increased. Drreddys Net profits 2017$1,257.20,2018-912.401$ and 2019-1,906.20 . It depicts that growing profitability position. 2017- 1,042.41, 2018$1,419.35$ and 20191,509.61. This position reveals that very good growth position of the company.

The sales position of Sun pharma beginning was low later gradually increased. See about Drreddys sales small changes occurred and Cipla was in increasing position.

Altman Z- Score Analysis reveals that financial wealth of the Sun Pharma, Drreddys and Cipla companies.

Published By:

Blue Eyes Intelligence Engineering 
Sun Pharma Z score shows that in the year of 2017 is 2.11 . The financial viability is considered healthy, 2018 is 1.85 and 2019-2.04. It shows financial health of the company. The failure of this situation considered is uncertain to predict. Drreddys score is 2017- 1.91, 2018-1.97 and 20192.29. This shows that healthy financial position of the company. Cipla z-score is 2017-2.21,2018-2.31 and 20192.4. This score shows that healthy financial position of the company.

\section{FINDINGS AND SUGGESTIONS}

The researcher found based on analysis on this research paper. They are as follows.

1. Table No.6 the net profit position of Sun Pharma is decreased year on year. Dr.Reddys net profit ratio 2018 decreased then increased. For Cipla net profit ratio its increased later slightly decreased.

2. Table No.10 shows that the financial health of Sun pharma is gradually increased. Even during the last year. Because the sales of company year on year was decreased and increased. So that profit also decreased slightly due to increasing finance cost and employee benefit expenses. But Sun Pharma is financially moderate position. DrReddys financial performance is strong position. Because from beginning of the period sales was grown well. This helped to earn higher level of profit. Based on Altmen $Z$ Score analysis the fianancial performance of Cipla company is in strongly healthy position. Because the revenue is increasing year on year.

The researcher suggested based on the analysis the above listed pharmaceutical companies mainly concentrated on various expenses. Like financial cost, employee benefit expenses. Due to increasing expenses the companies will lose their profitability position.

\section{CONCLUSION}

This study attempt to show the financial strength and weakness of the selected pharmaceutical companies in India. To evaluate the financial performance and conditions of company, this study uses Trend analysis , Ratio analysis and Altman Z- Score. The companies try to maximizing profit and sales and minimizing the various expenses. It can be improved financial position of the company.

\section{REFERNCES}

1. A small Financial report of Pharmaceutical Industries in India in March 2019.

2. Annual Report of the companies.

3. 'Profitability Analysis of Drugs and Pharmaceutical Companies in India', $\mathrm{Ph}$. D. thesis submitted to Saurashtra University by Akhileshwar Sharma 1992.

4. Altman, EI 1968, 'Financial Ratios, Discriminate Analysis and the Prediction of Corporate Bankruptcy', The Journal of Finance, vol.4, pp. 589-609.

5. Moneycontrol.com

6. Fundoodata.com

7. Economicstimesofindia. Com

\section{AUTHORS PROFILE}

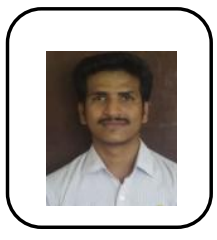

Mr. A. Jalaludeen, have completed M.Com. MBA.,SET(COM), NET(COM).,SET (MGT)., TTM And $\mathrm{i}$ am doing $\mathrm{Ph} . \mathrm{D}$ in Commerce in Jamal Mohamed College, Trichy. Also working as a Assistant professor at SRM Institute of Science and Technology, Chennai. I heve 7 years of working experience in teaching.

Dr. M. Marimuthu, have completed M.Com., MBA., B.Ed., NET., Ph. D. I am working as a Assistant Professor at PG \& Research Department of Commerce in Jamal Mohamed College, Trichy. I have produced more than $7 \mathrm{Ph} . \mathrm{D}$ research scholars and at present 5 research scholars doing $\mathrm{Ph} . \mathrm{D}$ under the guidance of me. 